\title{
Grand challenges in cancer epidemiology and prevention
}

\author{
Farhad Islami ${ }^{1,2}$, Farin Kamangar ${ }^{2,3}$ and Paolo Boffetta ${ }^{4,5 *}$ \\ 1 International Agency for Research on Cancer, Lyon, France \\ 2 Digestive Disease Research Center, Shariati Hospital, Tehran University of Medical Sciences, Tehran, Iran \\ ${ }^{3}$ Department of Public Health Analysis, School of Community Health and Policy, Morgan State University, Baltimore, MD, USA \\ ${ }^{4}$ The Tisch Cancer Institute and Institute for Transitional Epidemiology, Mount Sinai School of Medicine, New York, NY, USA \\ 5 International Prevention Research Institute, Lyon, France \\ *Correspondence: paolo.boffetta@mssm.edu
}

Cancer is the second cause of overall mortality in the world (Abegunde et al., 2007), with approximately 12.5 million new cases and 7.5 million deaths each year (Ferlay et al., 2010; Jemal et al., 2011). Many cancers are preventable, and cancer control represents a global challenge which will be significantly aided by increasing our knowledge of distribution, causes, and methods for prevention of cancer. This journal, Frontiers in Cancer Epidemiology and Prevention, is dedicated to publishing papers on the distribution, etiology, and prevention of cancer. In this article, we present our vision for the Journal. We discuss what has been discovered, what lies ahead, and what papers we hope to receive from authors. The overall scope of the Journal is summarized in Figure 1.

In the past few decades, cancer registries have produced data on incidence, prevalence, and mortality of cancers in many regions of the world, and shown variations by sex, race, geographic region, and other demographic determinants. Examples include the Surveillance Epidemiology and End Results (SEER) program in the United States (Hayat et al., 2007) and the compilation of cancer registry data within the volumes of Cancer Incidence in Five Continents (Parkin et al., 2010). We now have a reasonably good idea of distribution of cancers in many areas of the world, overall and within specific subgroups of the population. This is a unique and fortunate characteristic of the descriptive epidemiology of cancer, compared to other chronic diseases. However, cancer incidence and mortality rates change; hospitals and cancer registries prepare new reports; and new registries are established. We welcome reports on the incidence, prevalence, and mortality from cancers from all over the world and manuscripts based on original analyses of descriptive data.
Whereas by 1950 little was established about etiology of cancer, epidemiologic studies in the past 60 years have helped us know about some major causes of many cancers. One can cite many examples. Groundbreaking case-control studies by Doll and Hill (1950), Wynder and Graham (1950), and Levin et al. (1950) in the early 1950s established smoking as a cause of cancer. In the past two decades, a large number of case-control, cohort, and nested casecontrol studies showed the strong association between certain types of human papillomavirus (HPV) and cervical cancer, and later cancers of the vulva, vagina, penis, anus, oral cavity, and oropharynx and tonsil (Munoz et al., 2003; Bouvard et al., 2009). The causal role of hepatitis B virus (HBV) and hepatitis $\mathrm{C}$ virus (HCV) infection in hepatocellular carcinoma (Bouvard et al., 2009) and of several occupational exposures in a variety of cancers (Baan et al., 2009) are other important examples. Likewise, since 2006, genome-wide association studies have shown over 100 associations between common genetic polymorphisms and risk of various cancers (Stadler et al., 2010). Notwithstanding these discoveries, there remains much to be understood in relation to the etiology of cancer. Association of physical activity (Prentice et al., 2004; Reeves et al., 2007), shift-working (Straif et al., 2007; Stevens et al., 2011), and exposure to many chemical agents and mixtures (Ritz and Rull, 2008; Olsson et al., 2011) with cancer are a few examples. Studying environmental risk factors of cancer, from childhood, in repeated measures, with considering potential modifying effect of other factors such as microbiome, and in the light of development and teratogenesis, may increase our understanding of cancer risk factors (Wild, 2005, 2011; Hanash, 2011; Perera, 2011; Potter, 2011; Rappaport, 2011; Spitz, 2011). The continuing decline in cost of sequencing will make it possible to identify rare polymorphisms that strongly increase risk of cancer. The Journal welcomes reports on new factors associated with risk of cancer that may have a possible etiologic role, as well as null results from high-quality studies.

Epidemiologic studies can use new instruments or refine modeling to provide better understanding of the causes of cancer. For example, it has been suggested that, compared to food frequency questionnaires, using multiple 24 -h recalls may increase our ability to measure diet more accurately and hence reduce measurement error (Schatzkin et al., 2009b). During the past few decades, a wide range of biomarkers has also been applied to cancer epidemiology (Boffetta, 2010; Hartman et al., 2010). A classic example of successful application of biomarkers in cancer epidemiology is the study between aflatoxins and risk of hepatocellular carcinoma (Ross et al., 1992). However, intraindividual variability (e.g., diurnal variation in hormonal level) and measurement error (e.g., sampling and laboratory variation) do also occur with biomarkers, and most biomarker studies rely on a single biological sample, which may not represent longterm exposures. Many investigations are being conducted to identify new biomarkers and improve the validity and precision of existing biomarkers. Cancer results from a complex interplay of environmental, genetic, and epigenetic factors (Spitz and Bondy, 2010). New modeling strategies have increased our ability to more accurately study well-established associations such as the association between smoking and lung cancer (Lubin et al., 2008), as well as the association of diet (Ferrari et al., 2008; Schatzkin et al., 2009a) or genetic factors (Pashayan et al., 2011; Wakefield et al., 2010) with cancer, and to better control the effects of confounding factors (de Vocht et al., 


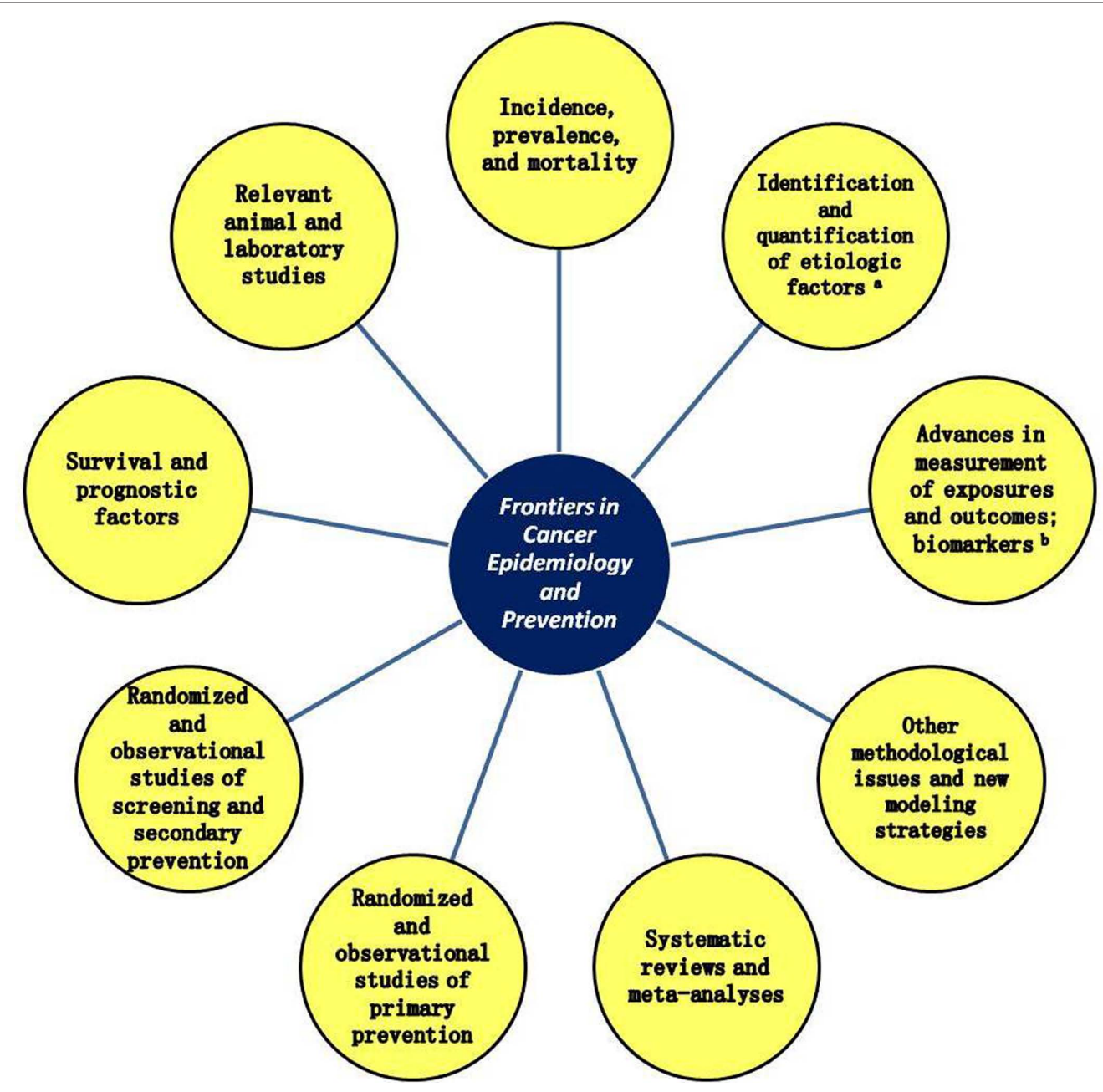

FIGURE 1 | Cancer research areas that are within the scope of Frontiers in Cancer Epidemiology and Prevention*.

*Null results from high-quality studies are also welcome.

alncluding environmental, genetic, and epigenetic factors and their interactions.

bIncluding advances in data collection methods and biomarkers, as well as translational studies.

2009). The Journal accepts papers on new instruments or biomarkers, improved statistical models, and also stronger studies of previously known associations.

Study subjects in epidemiological studies generally have heterogeneous environmental exposures and genetic background, which interact with each other and may influence the association between risk factors and health outcomes. In order to study such interactions, epidemiologic studies require large sample sizes, and therefore epidemiology falls into the category of "big science" (Kreeger, 2003). Large cohort studies, pooling and consortia of several studies, networks, and "networks of networks" have been helpful in achieving large sample sizes and to study interactions
(Brennan et al., 2004; Allen et al., 2009; Hashibe et al., 2009; Cook et al., 2010; Gallicchio et al., 2010; Zheng et al., 2011). Requirements and considerations for successful execution of large studies and making fruitful collaborations between multiple groups have been discussed elsewhere (Boffetta et al., 2011). We invite papers from such consortia and large-scale studies.

Cancer prevention, using the knowledge from epidemiology and molecular biology, has achieved many successes. Recognition of smoking as an important cause of lung cancer has resulted in smoking control policies in Europe, the United States, and some other countries (Chaloupka et al., 2011) that have in turn reduced exposure to tobacco smoke
(Callinan et al., 2010) and are expected to reduce the burden of tobacco-related cancers in those populations (Alberg et al., 2007; Sturgis and Cinciripini, 2007). Discovery of HPV as a cause of cervical cancer has successfully led to the development of effective vaccines against potent carcinogenic types of HPV (Monsonego et al., 2010). Global vaccination of newborns against $\mathrm{HBV}$ is another example of success that has reduced the rate of hepatocellular carcinoma in Taiwan (Chang et al., 2009) and would likely lead to serious declines in the worldwide rates in the coming decades (Yang and Roberts, 2010). Rapid reduction of the cost of genetic information has made it possible to screen and take actions when cancer risk 
is very high, such as in individuals with certain BRCA1 mutations (Balmana et al., 2010). On the other hand, cancer prevention science has also faced many failures. A number of initially promising agents were later shown to have either no effect or even cause harm. Well-known examples include the failure of alpha-tocopherol and betacarotene in preventing lung cancer (The Alpha-Tocopherol, Beta Carotene Cancer Prevention Study Group, 1994) and failure of selenium in preventing prostate cancer (Lippman et al., 2009). The Journal invites papers on new findings and methods on cancer prevention research. We are interested in receiving papers on both successes and failures of agents that are hypothesized to prevent cancer, including chemopreventive agents, vaccines, or lifestyle modification. We especially encourage submission of randomized clinical trials.

The Journal also accepts papers on screening and secondary prevention of cancer. It has now been well established that early screening for cervical, colorectal, and breast cancers through various methods can save lives (Sankaranarayanan et al., 2009; Schiffman and Solomon, 2009; US Preventive Services Task Force, 2009; Cunningham et al., 2010). New screening methods are being continuously devised; criteria are revised by age and sex; and revisions are made due to changes in effectiveness of treatments and invasiveness and cost of procedures. Screening studies are subject to a number of potential biases (Croswell et al., 2010), and new studies often refine previous studies and correct for biases. Publications of high-quality screening studies are within the scope of this Journal.

With rising availability of early detection facilities and more efficient treatments, survival of cancer patients has increased overall (Jemal et al., 2010). Survival has been shown to be related to a number of factors, including cancer site (e.g., breast versus pancreatic cancer), stage, age, other demographic, lifestyle, and genetic factors, as well as availability of facilities for early diagnosis or treatment of cancers. Consequently, cancer survival can vary across individuals and populations (Kamangar et al., 2006b; Jemal et al., 2010; Slatore et al., 2010; Coleman et al., 2011). However, many prognostic factors are not yet known. For example, low-cost sequencing may enable us to predict survival much more accurately. Some prognostic factors are modifiable and active secondary prevention activities can be undertaken to prolong survival. For example, improving awareness of effective screening methods and enhancing health services to offer such screening could lead to downstaging of cancers. We welcome reports on survival of cancer patients and its prognostic factors, and also research on methods leading clinical downstaging of cancers.

In addition to original research papers, we encourage authors to submit review articles, systematic reviews, and metaanalyses. These articles help establish or exclude associations (Kellen et al., 2007; Islami and Kamangar, 2008; Renehan et al., 2008; Lee et al., 2009; Turati et al., 2010; Gandini et al., 2011), revise estimates of initially inflated associations that may happen due to publication bias (Kamangar et al., 2006a), suggest associations or interactions relevant to cancer research (Minelli et al., 2011), or identify gaps in a research field (Islami et al., 2009).

Whereas the Journal is mainly dedicated to human studies, we also invite papers on animal or laboratory studies that have a direct relevance to cancer prevention in humans (Kern et al., 1991; Kim et al., 1991; Jokelainen et al., 1994; Watanabe et al., 1998; Wang et al., 2010). For example, papers that show high amounts of mutagenic or carcinogenic substances in certain foods and beverages (Zhang et al., 1983; Kamangar et al., 2008; Perello et al., 2008) will fall in the repertoire of this Journal.

In summary, while we have learned much about the distribution, etiology, primary and secondary prevention of cancer in one century of systematic research, many things remain to be learned. Development of large-scale trials and cohort studies, consortia of analytical epidemiology studies, new statistical methods, novel measurement methods, ever-increasing ability to sequence genome, among other factors, are giving us the opportunity to delve more deeply into research questions. We believe that Frontiers in Cancer Epidemiology and Prevention will play an important role in disseminating new knowledge in this field and can increase communication among basic scientists, epidemiologists, clinicians, and public health professionals in the field of oncology.

\section{REFERENCES}

Abegunde, D. O., Mathers, C. D., Adam, T., Ortegon, M., and Strong, K. (2007). The burden and costs of chronic diseases in low-income and middle-income countries. Lancet 370, 1929-1938.

Alberg, A. J., Ford, J. G., and Samet, J. M. (2007). Epidemiology of lung cancer: ACCP evidence-based clinical practice guidelines (2nd edition). Chest 132, 29S-55S.

Allen, N. E., Beral, V., Casabonne, D., Kan, S. W., Reeves, G. K., Brown, A., and Green, J. (2009). Moderate alcohol intake and cancer incidence in women. J. Natl. Cancer Inst. 101, 296-305.

Baan, R., Grosse, Y., Straif, K., Secretan, B., El Ghissassi, F., Bouvard, V., Benbrahim-Tallaa, L., Guha, N., Freeman, C., Galichet, L., and Cogliano, V. (2009). A review of human carcinogens - part F: chemical agents and related occupations. Lancet Oncol. 10, 1143-1144.

Balmana, J., Diez, O., Rubio, I., and Castiglione, M. (2010). BRCA in breast cancer: ESMO Clinical Practice Guidelines. Ann. Oncol. 21(Suppl. 5), v20-v22.

Boffetta, P. (2010). Biomarkers in cancer epidemiology: an integrative approach. Carcinogenesis 31, 121-126.

Boffetta, P., Colditz, G. A., Potter, J. D., Kolonel, L., Robson, P. J., Malekzadeh, R., Seminara, D., Goode, E. L., Yoo, K. Y., Demers, P., Gallagher, R., Prentice, R., Yasui, Y., O’Doherty, K., Petersen, G. M., Ulrich, C. M., Csizmadi, I., Amankwah, E. K., Brockton, N. T., Kopciuk, K., McGregor, S. E., and Kelemen, L. E. (2011).Cohorts and consortia conference: a summary report (Banff, Canada, June 17-19, 2009). Cancer Causes Control 22, 463-468.

Bouvard, V., Baan, R., Straif, K., Grosse, Y., Secretan, B., El Ghissassi, F., Benbrahim-Tallaa, L., Guha, N., Freeman, C., Galichet, L., and Cogliano, V. (2009). A review of human carcinogens - part B: biological agents. Lancet Oncol. 10, 321-322.

Brennan, P., Lewis, S., Hashibe, M., Bell, D. A., Boffetta, P., Bouchardy, C., Caporaso, N., Chen, C., Coutelle, C., Diehl, S. R., Hayes, R. B., Olshan, A. F., Schwartz, S. M., Sturgis, E. M., Wei, Q., Zavras, A. I., and Benhamou, S. (2004). Pooled analysis of alcohol dehydrogenase genotypes and head and neck cancer: a HuGE review. Am. J. Epidemiol. 159, 1-16.

Callinan, J. E., Clarke, A., Doherty, K., and Kelleher, C. (2010). Legislative smoking bans for reducing secondhand smoke exposure, smoking prevalence and tobacco consumption. Cochrane Database Syst. Rev. CD005992.

Chaloupka, F. J., Straif, K., and Leon, M. E. (2011). Effectiveness of tax and price policies in tobacco control. Tob. Control 20, 235-238.

Chang, M. H., You, S. L., Chen, C. J., Liu, C. J., Lee, C. M., Lin, S. M., Chu, H. C., Wu, T. C., Yang, S. S., Kuo, H. S., and Chen, D. S. (2009). Decreased incidence of hepatocellular carcinoma in hepatitis B vaccines: a 20-year follow-up study. J. Natl. Cancer Inst. 101, 1348-1355.

Coleman, M. P., Forman, D., Bryant, H., Butler, J., Rachet, B., Maringe, C., Nur, U., Tracey, E., Coory, M., Hatcher, J., McGahan, C. E., Turner, D., Marrett, L., Gjerstorff, M. L., Johannesen, T. B., Adolfsson, J., Lambe, M., Lawrence, G., Meechan, D., Morris, E. J., Middleton, R., Steward, J., and Richards, M. A. (2011). Cancer survival in Australia, Canada, Denmark, Norway, Sweden, and the UK, 1995-2007 (the International Cancer Benchmarking Partnership): an analysis of population-based cancer registry data. Lancet 377, 127-138. 
Cook, M. B., Kamangar, F., Whiteman, D. C., Freedman, N. D., Gammon, M. D., Bernstein, L., Brown, L. M., Risch, H. A., Ye, W., Sharp, L., Pandeya, N., Webb, P. M., Wu, A. H., Ward, M. H., Giffen, C., Casson, A. G., Abnet, C. C., Murray, L. J., Corley, D. A., Nyren, O., Vaughan, T. L., and Chow, W. H. (2010). Cigarette smoking and adenocarcinomas of the esophagus and esophagogastric junction: a pooled analysis from the international BEACON consortium. J. Natl. Cancer Inst. 102, 1344-1353.

Croswell, J. M., Ransohoff, D. F., and Kramer, B. S. (2010). Principles of cancer screening: lessons from history and study design issues. Semin. Oncol. 37, 202-215.

Cunningham, D., Atkin, W., Lenz, H. J., Lynch, H. T., Minsky, B., Nordlinger, B., and Starling, N. (2010). Colorectal cancer. Lancet 375, 1030-1047.

de Vocht, F., Kromhout, H., Ferro, G., Boffetta, P., and Burstyn, I. (2009). Bayesian modelling of lung cancer risk and bitumen fume exposure adjusted for unmeasured confounding by smoking. Occup. Environ. Med. 66, 502-508.

Doll, R., and Hill, A. B. (1950). Smoking and carcinoma of the lung: preliminary report. Br. Med. J. 2, 739-748.

Ferlay, J., Shin, H. R., Bray, F., Forman, D., Mathers, C., and Parkin, D. M. (2010). Estimates of worldwide burden of cancer in 2008: GLOBOCAN 2008. Int. J. Cancer. 127, 2893-2917.

Ferrari, P., Carroll, R. J., Gustafson, P., and Riboli, E. (2008). A Bayesian multilevel model for estimating the diet/disease relationship in a multicenter study with exposures measured with error: the EPIC study. Stat. Med. 27, 6037-6054.

Gallicchio, L., Helzlsouer, K. J., Chow, W. H., Freedman, D. M., Hankinson, S. E., Hartge, P., Hartmuller, V., Harvey, C., Hayes, R. B., Horst, R. L., Koenig, K. L., Kolonel, L. N., Laden, F., McCullough, M. L., Parisi, D., Purdue, M. P., Shu, X. O., Snyder, K., StolzenbergSolomon, R.Z., Tworoger, S. S., Varanasi, A., Virtamo, J., Wilkens, L. R., Xiang, Y. B., Yu, K., ZeleniuchJacquotte, A., Zheng, W., Abnet, C. C., Albanes, D. Bertrand, K., and Weinstein, S. J. (2010). Circulating 25-hydroxyvitamin D and the risk of rarer cancers: design and methods of the Cohort Consortium Vitamin D Pooling Project of Rarer Cancers. Am. J. Epidemiol. 172, 10-20.

Gandini, S., Boniol, M., Haukka, J., Byrnes, G., Cox, B., Sneyd, M. J., Mullie, P., and Autier, P. (2011). Meta-analysis of observational studies of serum 25-hydroxyvitamin D levels and colorectal, breast and prostate cancer and colorectal adenoma. Int. J. Cancer 128, 1414-1424.

Hanash, S. (2011). Harnessing the immune response for cancer detection. Cancer Epidemiol. Biomarkers Prev. 20, 569-570.

Hartman, M., Loy, E. Y., Ku, C. S., and Chia, K. S. (2010). Molecular epidemiology and its current clinical use in cancer management. Lancet Oncol. 11, 383-390.

Hashibe, M., Brennan, P., Chuang, S. C., Boccia, S., Castellsague, X., Chen, C., Curado, M. P., Dal Maso, L., Daudt, A. W., Fabianova, E., Fernandez, L., Wunsch-Filho, V., Franceschi, S., Hayes, R. B., Herrero, R., Kelsey, K., Koifman, S., La Vecchia, C., Lazarus, P., Levi, F., Lence, J. J., Mates, D., Matos, E., Menezes, A., McClean, M. D., Muscat, J., Eluf-Neto, J., Olshan, A. F., Purdue, M., Rudnai, P., Schwartz, S. M., Smith, E., Sturgis, E. M., Szeszenia-Dabrowska, N., Talamini, R., Wei, Q., Winn, D. M., Shangina, O., Pilarska, A., Zhang, Z. F., Ferro, G., Berthiller, J., and Boffetta, P. (2009). Interaction between tobacco and alcohol use and the risk of head and neck cancer: pooled analysis in the International Head and Neck Cancer Epidemiology Consortium. Cancer Epidemiol. Biomarkers Prev. 18, 541-550.

Hayat, M. J., Howlader, N., Reichman, M. E., and Edwards, B. K. (2007). Cancer statistics, trends, and multiple primary cancer analyses from the Surveillance, Epidemiology, and End Results (SEER) Program. Oncologist 12, 20-37.

Islami, F., Boffetta, P., Ren, J. S., Pedoeim, L., Khatib, D., and Kamangar, F. (2009). High-temperature beverages and foods and esophageal cancer risk - a systematic review. Int. J. Cancer 125, 491-524.

Islami, F., and Kamangar, F. (2008). Helicobacter pylori and esophageal cancer risk: a meta-analysis. Cancer Prev. Res. (Phila) 1, 329-338.

Jemal, A., Bray, F., Center, M. M., Ferlay, J., Ward, E., and Forman, D. (2011). Global cancer statistics. CA Cancer J. Clin. 61, 69-90.

Jemal, A., Siegel, R., Xu, J., and Ward, E. (2010). Cancer statistics, 2010. CA Cancer J. Clin. 60, 277-300.

Jokelainen, K., Roine, R. P., Vaananen, H., Farkkila, M., and Salaspuro, M. (1994). In vitro acetaldehyde formation by human colonic bacteria. Gut 35, 1271-1274.

Kamangar, F., Cheng, C., Abnet, C. C., and Rabkin, C. S. (2006a). Interleukin-1B polymorphisms and gastric cancer risk - a meta-analysis. Cancer Epidemiol. Biomarkers Prev. 15, 1920-1928.

Kamangar, F., Dores, G. M., and Anderson, W. F. (2006b). Patterns of cancer incidence, mortality, and prevalence across five continents: defining priorities to reduce cancer disparities in different geographic regions of the world. J. Clin. Oncol. 24, 2137-2150.

Kamangar, F., Schantz, M. M., Abnet, C. C., Fagundes, R. B., and Dawsey, S. M. (2008). High levels of carcinogenic polycyclic aromatic hydrocarbons in mate drinks. Cancer Epidemiol. Biomarkers Prev. 17, 1262-1268.

Kellen, E., Hemelt, M., Broberg, K., Golka, K., Kristensen, V. N., Hung, R. J., Matullo, G., Mittal, R. D., Porru, S., Povey, A., Schulz, W. A., Shen, J., Buntinx, F., Zeegers, M. P., and Taioli, E. (2007). Pooled analysis and metaanalysis of the glutathione S-transferase P1 Ile 105Val polymorphism and bladder cancer: a HuGE-GSEC review. Am. J. Epidemiol. 165, 1221-1230.

Kern, S. E., Kinzler, K. W., Bruskin, A., Jarosz, D., Friedman, P., Prives, C., and Vogelstein, B. (1991). Identification of p53 as a sequence-specific DNAbinding protein. Science 252, 1708-1711.

Kim, C. M., Koike, K., Saito, I., Miyamura, T., and Jay, G. (1991). HBx gene of hepatitis B virus induces liver cancer in transgenic mice. Nature 351, 317-320.

Kreeger, K. (2003). Consortia, "big science" part of a paradigm shift for genetic epidemiology. J. Natl. Cancer Inst. 95, 640-641.

Lee, Y. C., Cohet, C., Yang, Y. C., Stayner, L., Hashibe, M., and Straif, K. (2009). Meta-analysis of epidemiologic studies on cigarette smoking and liver cancer. Int. J. Epidemiol. 38, 1497-1511.

Levin, M. L., Goldstein, H., and Gerhardt, P. R. (1950). Cancer and tobacco smoking: a preliminary report. J. Am. Med. Assoc. 143, 336-338.

Lippman, S. M., Klein, E. A., Goodman, P. J., Lucia, M. S., Thompson, I. M., Ford, L. G., Parnes, H. L., Minasian, L. M., Gaziano, J. M., Hartline, J. A., Parsons, J. K., Bearden, J. D. III, Crawford, E. D., Goodman, G. E., Claudio, J., Winquist, E., Cook, E. D., Karp, D. D., Walther, P., Lieber, M. M., Kristal, A. R., Darke, A. K., Arnold, K. B., Ganz, P.A., Santella, R. M., Albanes, D.,
Taylor, P. R., Probstfield, J. L., Jagpal, T. J., Crowley, J. J., Meyskens, F. L. Jr., Baker, L. H., and Coltman, C. A Jr. (2009). Effect of selenium and vitamin E on risk of prostate cancer and other cancers: the Selenium and Vitamin E Cancer Prevention Trial (SELECT). JAMA 301, 39-51.

Lubin, J. H., Virtamo, J., Weinstein, S. J., and Albanes, D. (2008). Cigarette smoking and cancer: intensity patterns in the alpha-tocopherol, beta-carotene cancer prevention study in Finnish men. Am. J. Epidemiol. 167, 970-975.

Minelli, C., Wei, I., Sagoo, G., Jarvis, D., Shaheen, S., and Burney, P. (2011). Interactive effects of antioxidant genes and air pollution on respiratory function and airway disease: a HuGE review. Am. J. Epidemiol. 173, 603-620.

Monsonego, J., Cortes, J., Greppe, C., Hampl, M., Joura, E., and Singer, A. (2010). Benefits of vaccinating young adult women with a prophylactic quadrivalent human papillomavirus (types $6,11,16$ and 18) vaccine. Vaccine 28, 8065-8072.

Munoz, N., Bosch, F. X., de Sanjosé, S., Herrero, R., Castellsague, X., Shah, K. V., Snijders, P. J., and Meijer, C. J. (2003). Epidemiologic classification of human papillomavirus types associated with cervical cancer. N. Engl. J. Med. 348, 518-527.

Olsson, A. C., Gustavsson, P., Kromhout, H., Peters, S., Vermeulen, R., Bruske, I., Pesch, B., Siemiatycki, J., Pintos, J., Bruning, T., Cassidy, A., Wichmann, H. E., Consonni, D., Landi, M. T., Caporaso, N., Plato, N., Merletti, F., Mirabelli, D., Richiardi, L., Jockel, K. H., Ahrens, W., Pohlabeln, H., Lissowska, J., SzeszeniaDabrowska, N., Zaridze, D., Stucker, I., Benhamou, S., Bencko, V., Foretova, L., Janout, V., Rudnai, P., Fabianova, E., Stanescu, D. R., Gross, I. M., Kendzia, B., Forastiere, F., Bueno-de-Mesquita, B., Brennan, P., Boffetta, P., and Straif, K. (2011). Exposure to diesel motor exhaust and lung cancer risk in a pooled analysis from case-control studies in Europe and Canada. Am J Respir. Crit. Care Med. 183, 941-948.

Parkin, D. M., Ferlay, J., Curado, M. P., Bray, F., Edwards, B., Shin, H. R., and Forman, D. (2010). Fifty years of cancer incidence: CI5 I-IX. Int. J. Cancer 127, 2918-2927.

Pashayan, N., Pharoah, P., Tabar, L., Neal, D. E., Martin, R. M., Donovan, J., Hamdy, F., and Duffy, S. W. (2011). Validation of a modelling approach for estimating the likely effectiveness of cancer screening using cancer data on prevalence screening and incidence. Cancer Epidemiol. 35, 139-144.

Perello, G., Marti-Cid, R., Castell, V., Llobet, J. M., and Domingo, J. L. (2008). Concentrations of polybrominated diphenyl ethers, hexachlorobenzene and polycyclic aromatic hydrocarbons in various foodstuffs before and after cooking. Food Chem. Toxicol. 47, 709-715.

Perera, F. P. (2011). Cancer: the big questions to address in coming years. Cancer Epidemiol. Biomarkers Prev. 20, 571-573.

Potter, J. D. (2011). Development and the environment: clues to carcinogenesis. Cancer Epidemiol. Biomarkers Prev. 20, 574-577.

Prentice, R. L., Willett, W. C., Greenwald, P., Alberts, D., Bernstein, L., Boyd, N. F., Byers, T., Clinton, S. K., Fraser, G., Freedman, L., Hunter, D., Kipnis, V., Kolonel, L. N., Kristal, B. S., Kristal, A., Lampe, J. W., McTiernan, A., Milner, J., Patterson, R. E., Potter, J. D., Riboli, E., Schatzkin, A., Yates, A., and Yetley, E. (2004). Nutrition and physical activity and chronic disease 
prevention: research strategies and recommendations. J. Natl. Cancer Inst. 96, 1276-1287.

Rappaport, S. M. (2011). Implications of the exposome for exposure science. J. Expo. Sci. Environ. Epidemiol. 21, 5-9.

Reeves, G. K., Pirie, K., Beral, V., Green, J., Spencer, E., and Bull, D. (2007). Cancer incidence and mortality in relation to body mass index in the Million Women Study: cohort study. BMJ 335, 1134.

Renehan, A. G., Tyson, M., Egger, M., Heller, R. F., and Zwahlen, M. (2008). Body-mass index and incidence of cancer: a systematic review and meta-analysis of prospective observational studies. Lancet 371, 569-578.

Ritz, B., and Rull, R.P. (2008). Assessment of environmental exposures from agricultural pesticides in childhood leukaemia studies: challenges and opportunities. Radiat. Prot. Dosimetry 132, 148-155.

Ross, R. K., Yuan, J. M., Yu, M. C., Wogan, G. N., Qian, G. S., Tu, J. T., Groopman, J. D., Gao, Y.T., and Henderson, B. E. (1992). Urinary aflatoxin biomarkers and risk of hepatocellular carcinoma. Lancet 339, 943-946.

Sankaranarayanan, R., Nene, B. M., Shastri, S. S., Jayant, K., Muwonge, R., Budukh, A. M., Hingmire, S., Malvi, S. G., Thorat, R., Kothari, A., Chinoy, R., Kelkar, R., Kane, S., Desai, S., Keskar, V. R., Rajeshwarkar, R., Panse, N., and Dinshaw, K. A. (2009). HPV screening for cervical cancer in rural India. N. Engl. J. Med. 360, 1385-1394.

Schatzkin, A., Abnet, C. C., Cross, A. J., Gunter, M., Pfeiffer, R., Gail, M., Lim, U., and Davey-Smith, G. (2009a). Mendelian randomization: how it can - and cannot-help confirm causal relations between nutrition and cancer. Cancer Prev. Res. (Phila) 2, 104-113.

Schatzkin, A., Subar, A. F., Moore, S., Park, Y., Potischman, N., Thompson, F. E., Leitzmann, M., Hollenbeck, A., Morrissey, K. G., and Kipnis, V. (2009b). Observational epidemiologic studies of nutrition and cancer: the next generation (with better observation). Cancer Epidemiol. Biomarkers Prev. 18, 1026-1032.

Schiffman, M., and Solomon, D. (2009). Screening and prevention methods for cervical cancer. JAMA 302, 1809-1810.

Slatore, C. G., Au, D. H., and Gould, M. K. (2010). An official American Thoracic Society systematic review: insurance status and disparities in lung cancer practices and outcomes. Am. J. Respir. Crit. Care Med. 182, 1195-1205.
Spitz, M. R. (2011). 'Confounding' our future. Cancer Epidemiol. Biomarkers Prev. 20, 578-579.

Spitz, M. R., and Bondy, M. L. (2010). The evolving discipline of molecular epidemiology of cancer. Carcinogenesis 31, 127-134.

Stadler, Z. K., Vijai, J., Thom, P., Kirchhoff, T., Hansen, N. A., Kauff, N. D., Robson, M., and Offit, K. (2010). Genome-wide association studies of cancer predisposition. Hematol. Oncol. Clin. North Am. 24, 973-996.

Stevens, R. G., Hansen, J., Costa, G., Haus, E., Kauppinen, T., Aronson, K. J., Castano-Vinyals, G., Davis, S., Frings-Dresen, M. H., Fritschi, L., Kogevinas, M., Kogi, K., Lie, J. A., Lowden, A., Peplonska, B., Pesch, B., Pukkala, E., Schernhammer, E., Travis, R. C., Vermeulen, R., Zheng, T., Cogliano, V., and Straif, K. (2011). Considerations of circadian impact for defining 'shift work' in cancer studies: IARC Working Group Report. Occup. Environ. Med. 68, 154-162.

Straif, K., Baan, R., Grosse, Y., Secretan, B., El, G. F., Bouvard, V., Altieri, A., brahim-Tallaa, L., and Cogliano, V. (2007). Carcinogenicity of shift-work, painting, and fire-fighting. Lancet Oncol. 8, 1065-1066.

Sturgis, E. M., and Cinciripini, P. M. (2007). Trends in head and neck cancer incidence in relation to smoking prevalence: an emerging epidemic of human papillomavirus-associated cancers? Cancer 110, 1429-1435.

The Alpha-Tocopherol, Beta Carotene Cancer Prevention Study Group. (1994). The effect of vitamin E and beta carotene on the incidence of lung cancer and other cancers in male smokers. N. Engl. J Med. 330, 1029-1035.

Turati, F., Gallus, S., Tavani, A., Tramacere, I., Polesel, J., Talamini, R., Montella, M., Scotti, L., Franceshi, S., and La, V.C. (2010). Alcohol and endometrial cancer risk: a case-control study and a meta-analysis. Cancer Causes Control 21, 1285-1296.

US Preventive Services Task Force. (2009). Screening for breast cancer: U.S. Preventive Services Task Force recommendation statement. Ann. Intern. Med. 151, 716-236.

Wakefield, J., de Vocht, F., and Hung, R. J. (2010). Bayesian mixture modeling of gene-environment and genegene interactions. Genet. Epidemiol. 34, 16-25.

Wang, R., Chadalavada, K., Wilshire, J., Kowalik, U., Hovinga, K. E., Geber, A., Fligelman, B., Leversha, M., Brennan, C., and Tabar, V. (2010). Glioblastoma stem-like cells give rise to tumour endothelium. Nature 468, 829-833.
Watanabe, T., Tada, M., Nagai, H., Sasaki, S., and Nakao, M. (1998). Helicobacter pyloriinfection induces gastric cancer in Mongolian gerbils. Gastroenterology 115, 642-648.

Wild, C. P. (2005). Complementing the genome with an "exposome": the outstanding challenge of environmental exposure measurement in molecular epidemiology. Cancer Epidemiol. Biomarkers Prev. $14,1847-1850$.

Wild, C. P. (2011). How much of a contribution do exposures experienced between conception and adolescence make to the burden of cancer in adults? Cancer Epidemiol. Biomarkers Prev. 20, 580-581.

Wynder, E. L., and Graham, E. A. (1950). Tobacco smoking as a possible etiologic factor in bronchiogenic carcinoma: a study of 684 proved cases. J. Am. Med. Assoc. 143, 329-336.

Yang, J. D., and Roberts, L. R. (2010). Hepatocellular carcinoma: a global view. Nat. Rev. Gastroenterol. Hepatol. 7, 448-458.

Zhang, W. X., Xu, M. S., Wang, G. H., and Wang, M. Y. (1983). Quantitative analysis of Roussin red methyl ester in pickled vegetables. Cancer Res. 43, 339-341.

Zheng, W., McLerran, D. F., Rolland, B., Zhang, X., Inoue, M., Matsuo, K., He, J., Gupta, P. C., Ramadas, K., Tsugane, S., Irie, F., Tamakoshi, A., Gao, Y. T., Wang, R., Shu, X. O., Tsuji, I., Kuriyama, S., Tanaka, H., Satoh, H., Chen, C. J., Yuan, J. M., Yoo, K. Y., Ahsan, H., Pan, W. H., Gu, D., Pednekar, M. S., Sauvaget, C., Sasazuki, S., Sairenchi, T., Yang, G., Xiang, Y. B., Nagai, M., Suzuki, T., Nishino, Y., You, S. L., Koh, W. P., Park, S. K., Chen, Y., Shen, C. Y., Thornquist, M., Feng, Z., Kang, D., Boffetta, P., and Potter, J. D. (2011). Association between body-mass index and risk of death in more than 1 million Asians. N. Engl. J. Med. 364, 719-729.

Received: 05 April 2011; accepted: 12 April 2011; published online: 27 April 2011.

Citation: Islami F, Kamangar F and Boffetta P (2011)

Grand challenges in cancer epidemiology and prevention. Front. Oncol. 1:3. doi: 10.3389/fonc.2011.00003

This article was submitted to Frontiers in Cancer Epidemiology and Prevention, a specialty of Frontiers in Oncology.

Copyright $\odot 2011$ Islami, Kamangar and Boffetta. This is an open-access article subject to a non-exclusive license between the authors and Frontiers Media SA, which permits use, distribution and reproduction in other forums, provided the original authors and source are credited and other Frontiers conditions are complied with. 